Int. Arch. Allergy 1957;11:129a-129b

\title{
Contents, Vol. 11, No. 3/4, 1957
}

\section{Part II}

Ouchterlony, Ö., $\quad$ The Gel-Precipitation Method and Its Applications in the Field of Goethenburg Allergy

Feinberg, J. G., Identification, Discrimination and Quantification in Ouchterlony Betchworth, Surrey Gel-Plates , . 129

Augustin, R., London Fundamental Aspects of Single versus Double Diffusion Methods for Immunological Assays 153

Stanworth, D. R., The Use of the Gel-Precipitation Technique in the Identification of Birmingham Horse Dandruff Allergen, and in the Study of the Serological

Relationship between Horse Dandruff and Horse Serum Proteins . 170

Leigh, D., London The Psychiatric Approach to Allergic Disorders

Hayward, B. J. and New Quantitative Gel-Diffusion Methods 192

Augustin, R., London

Dornbusch, S., Jena The Value of the Gel-Precipitation Method for the Study of AutoI $\pi$ ununological Problems 206

Discussion 213

Quarles van Ufford, Histamine Provocation and Histamine Treatment of Atopic Der-W. J., Utrechtmatitis 214

Augustin, R., London Pollen Antigens v. Pollen Allergens. Limiting Aspects of Gel-Diffusion for Assay Purposes in Allergy 218

Augustin, R., London Demonstration, by Gel-Diffusion, of an Instance of Drug Allergy 223

Panzani, R., Marseilles

Respiratory Castor Bean Dust Allergy in the South of France with

Special Reference to Marseilles 224

Officers and Membership Directory of the CIA

All rights, including that of translation into foreign languages, reserved. Photomechanic reproduction

(photocopy, microcopy) of this book or part of it without special permission of the publishers is prohibited.

(C)

Copyright 1957 by S. Karger AG,, Basel.

Printed in Switzerland by Buchdruckerei Aargauer Tagblatt, Aarau.

Cliches: Aberegg-Steiner \& Cie. AC, Bern, und Steiner \& Cie. AC, Basel. 